\title{
Pasteuria nishizawae sp. nov., a mycelial and endospore-forming bacterium parasitic on cyst nematodes of genera Heterodera and Globodera
}

\author{
R.M. Sayre ${ }^{13}$, W.P. Wergin ${ }^{2}$,

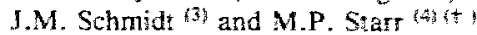

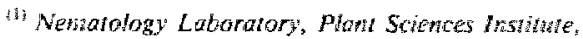 \\ Beitswile Agricultural Reward: Center, USDA ARS, \\ Betr5yille, MD 20705-2350,

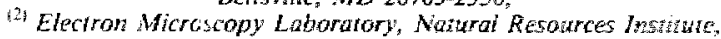 \\ Britsitle Agricultural Research Center, USDA-AFS" \\ Beltswille, MD 20705-2350, \\ t3i Deparment of Microbiology. \\ Arizong State University, Tempe, AZ $85287-270 t$, atot

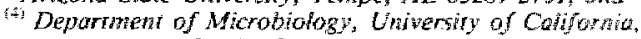 \\ Davis, CA 55616 (USA)
}

\begin{abstract}
SUMMARY
This study describes Pasteuria nishizawae sp. nov., a fourth species of the genus Pasteuria. This mycelial and endospere-forming bacterium parasitizes the aduit females of cyst-forming nematodes in the genera Heterodera and Globodera. The distinct uttrastructural features and unique host range found for this bacterium separate it from two closely related species, Pasteuria penetrans, which parasitizes several species of rootknot nematodes of the genus Meloidogyne, and Pasteunia thomei, which appears to parasitize only one species of the root-lesion nematode. Pratylenchus brachyurus. Because these obligate bacterial parasites of nematodes have not been cultured axenically, the taxonomic relationships described here for each species are tased mainiy on developmental morphology, fine structure of the respective sporangia and endospores, and their pathogenicity on nematode species.
\end{abstract}

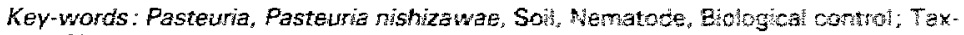
onomy, New species.

\section{NTRODLCTION}

The species currevtly assigned to the genus Pasieuria (Sayre and Star, 1989) and many of the other closely related bacterial pathogens, which remain to be chanderized, have not ben

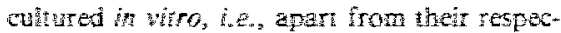
Wve nenatole hosts. Consequenty these hacseria are fomd primariy as a resuit of their

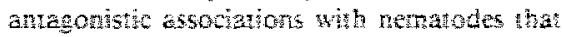

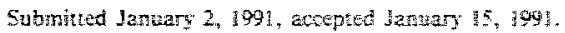

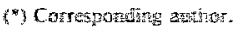

it Decassd Apr? 20, 3989. 
parasitize crop plants. The early morphological characterizations of endospores of Pasteuria have been documented in the taxonomic literature of nematodes (Cobb, 1906; Thorne, 1940, 1961 ; Williams, 1960). More recent investigations have described the true bacterial nature of these parasites of nematodes (Imbriani and Mankau, 1977; Mankau, 1975a,b; Mankau and Prasad, 1977). In pathogelic asseciations with nematodes, the bacterial species Pasteuria penetrans, $P$. thornei, and the cyst nemiztode Pasteuria (CNP), which is named in this study, convert the biomass of each parasitized host nematode into as many as $2 \times 10^{6}$ bacterial endospores per root-knot nematode carcass (figure 1). The cndospores, which are liberated into the soil from the remnants of the parasitized nematode, then attach to the cuticular surface of susceptible migratory J2s (fig. 2). When these nematodes continue their development, the attached bacterial endospores germinate and the germ tubes penetrate through cuticle into pseudocoelom where they form inycelia that eventuaily differentiate to produce endospores, thereby completing the life cycle of the bacterium (Sayre and Starr, 1985; Sayre and Wergin, 1977). Recently many studies have ascertained the potential benefits of the species Pasteuria as biocontro agents of the economically destructive plantparasitic nematodes (Brown et al., 1985; Mankau, 1973, 1980; Mankau and Prasad, 1972; Stirling, 1984, 1988). Because Pasteuria spp. have not been cultivated in vitro, investigators have worked with crude preparations, e.g., spores derived from a single "strain" of $P$. penetrans parasitizing a root-knot nematode of the genus Meloidogyne which, in iurn, was parasitizing tomato plants (Stirling and Wachte:, 1980 ). To continue investigations of these bacteria, this method remains indispensable; it does not yield isolates of a "single" bacterial strain for transfer and long term stability in reposito- ries. The probability that any one sample of several hundred diseased nematodes represents one strain is questioned, because a population of these bacterial parasites apparently consists of several taxa with limited host ranges (Sayre and Starr, 1985; Sayre et al., 1988). Because the limits of each actual or potential species in the genus Pasteuria are not known, one caution must now be made: Wherever the name $P$. penetrons (or its earlier synonyms, 'Duboscqia penetrans" or "Bacillus penetrans") appears in the literature, it might justifiably be replaced by "member(s) of the P. penetrans group", "a Pasteuria spp.", or a similar reference.

Taxonomic studies are available on $P$. ramosa (Sayre et al., 1983), P. penetrans (Sayre and Starr, 1985) and P. thornei (Sayre et al., 1988). The recent investigations of Nishizawa (1984, 1986, 1987) and others (Sayre et al, 1991) present additional information on another nember of this bacterial group, the cyst nematode Pasteuria (CNP). CNP parasitizes nematodes of the genera Heterodera and Globodera. We will present a summary of the observed differences among species of Pasteuria occurring in the cladoceran, Moina rectirostris and those that parasitize the following nematodes: Meloidogyne species, Pratylenchus brachyurus, Heterodera elachisia, Heterodera glycines and Globodera rostochiensis. The recently found bacterium that parasitizes cyst nematodes wil be described and named in this study.

\section{MATERIALS AND METHODS}

\section{Terminology}

The fine structure of the sporangia of bacterial parasites of nematodes will be used to taxonomically delineate species of Pasteuria. We have applied the terminology, which was suggested by Sussman and Halvorson (1966) and recently reviewed by Terson

\begin{tabular}{|c|c|c|}
\hline CNP & $=$ & cysi nematode Pasteuria. \\
\hline 32 & $=$ & infective scoond stage jirenge. \\
\hline L.M & $=$ & fight mickoscopy. \\
\hline LVFE(SEM) & $=$ & low roltage fizeld emission (SEM). \\
\hline RKN & $=$ & root-inol nematade. \\
\hline
\end{tabular}

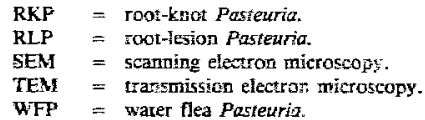


(1988), to our discussion of the structural details of the Pasteuria species. The following terminology is used in this study: (a) endospore; the single asexual spore that develops within a sporangium and may be enclosed by an exosporium; (b) plasma membrane: the innermost septum that surrounds the central protoplast ; (c) cortex: the electron-translucent band that opposes the plasma membrane; (d) inner coat : a narrow multilaminar band that lies exterior to the cortex; (e) outer coat: the wide outer electron-dense band; ( $f$ ) exosporium: the outermost membrane of a typical Gram-positive bacterial spore that surrounds the structures defined above. Within the exosporium, the Pasteuria spp. have two additional structures; (g) epicortical layer: a discontinuous, electron-dense band and varies in its appearance from species to species; and the (h) episporic layer: peripheral fibers that are an essential part of the endospore and allow for attachment to the nematode host.

\section{Material examined}

\section{Sources of host nematodes}

For laboratory bioassays, pure populations of the following nematodes were reared asepticaliy on root explanis (Lauritis et al., 1982, 1983a,b; Huettel and Rebois, 1985): Meloidogyne incognita, $P$. brachyurus, Heterodera zeate, and four races of $\boldsymbol{H}$. glycines. Individual nematode populations were harvested from the culture plates using the modified Bacrmann funriel technique of Niblack and Huang (1985). In the greenhouse and field studies where large populations of nematodes were needed, the following species were maintained in greenhouse pot cultures: M. incognita on tomato $\mathrm{ev}$. Marglobe or Tiny Tim; $M$. hapla on strawberry; $M$. javanica on tornato $\mathrm{c}$. Marglobe; $\boldsymbol{H}$. glycines on soybean cv. Kent; $\boldsymbol{H}$. zeae on corn cv. Iowa Chief; and $P$. brachyurus on peanut cv. Florarunner. The details for rearing $M$. incognita and $P$. brachyurus have teen previously reported (Sayre and Wergin, 1977; Sayre et al., 1988). H. glycines was maintained in the greenhouse on soybeans (cy. Kent). The nentatodes were extracted from soll using the methodology of Ayout (1980).

\section{Sources of the Pasteuria spp.}

The procedure of Stirling and Wachtel (1;80) was used to maintain cultures of $P$. penetrans on $M$. incognita. $P$. thornet indospores were obtained from the parasitized juveniles and adults of $P$. bracinyurus (Sayre ef al., 1988; Starr and Sayre, 1988). The infected nematodes obtained from the root of the peanut (cv. Flotarunner) were extracted in a misi chamber by the procedire of Chamman (1957). Cysts of $H$. glycines parasitized by CNP were imported from Japan. CNP was introduced into a population of $H$. glycines and then maintained in greenhouse pot cultures (Sayre et al., 1991).

\section{Microscopy and measurements}

\section{Light microscopy}

No new materials were prepared for $P$, ramosa $P$. penetrans or $P$. thornei. Alternatively, the archival collection of photomicrographic materials of thesp species, some of which were presented in previous publications (Sayre, Gherna and Wergin, 1983 ; Sayre and Starr, 1985; Sayre et al, 1988; Siarr and Sayre, 1988 ; and Sayre et al., 1991), were useri to compare structural features of these species with those of the CNP preparations. The preparative methods for $P$. ramosa, $P$. penetrans and $P$. thornei were similar to those used for CNP. Briefily, cysts of $H$. $g$ lycines found parasitized by CNP were selected from soil samples, crushed aud mounted on matroscope slidss in water using the kemporasy methed of Southey (1926). Photomicrographe of sporangia and other life stages of CNP were taken on "Kodak Tri- $X$ Pan" film processed in "Nicrodol- $X$ " using an attomatic exposure $35-\mathrm{mm}$ camerc attached to a corrpound microscope (Nikon Microphot $F-X$ ) fitted with an interference contrast system (figs. 1-3). Morphometric data were ottained by measuring images on the enlarged photomicrographe. Whenewer possible, 20 separate measurements were taken of each bacterial iffe siage, and presented as the mean plus or minus the standard deviation. The morphometric data of previous studies indicated that measurements taken of the life stages from light mieroscopy were greater than those obtained for identical features recorded by electron microscopy. This difference results from shrinkage of specimens that occurs during chernical fixation, dehydration and critizal point drying (Sayre et af., 1991). As a consequence, the morphometric data in table I indicates the procedure used to obtain each walue: light misroscopy (LM), scanning electron microscopy (SEM), transmission electron microstopy (TEM).

\section{Scanning electron micrascopy}

Nematode jife stages that had been encumbered or parasitized by CNP ware chemicaly fixed for SEM. The nematode specinens contuining the endospores of CNP were placed in 3.0 o solution of glutaraldehyde in $0.05 \mathrm{M}$ phosphate buffer $\mathrm{pH}$ 6.8) for 1.5 h and then debydrated in an ethatol series. Thereafter, the specimens were critical-print-dried, mounted on aluminum stubs, conated want hold- 
palladium, and examined with a "Hitachi" HiSS-2R, S430, or S530 SEM operating at 15 or $20 \mathrm{kV}$.

A new instrument (Wergin and Sayre, 1988; Wergin et al., 1988) known as a low voltage field emission SEM (LVFE-SEM) was also used in the examination of CNP.

\section{Transmission electron micrascopy}

For TEM, single cysts of $H$. glycines parasitized by CNP were hand-picked and individually placed in the wells of a microtitration piate (Falcon 3034) containing a droplet of tap water. The wells were ther filled with molten $3.0 \%$ water-agar at $50^{\circ} \mathrm{C}$. After solidification, agar cores containing the cysts were removed from the plate, placed in $3.0 \%$ glutaraldehyde in $0.05 \mathrm{M}$ phosphate buffer $(\mathrm{pH} \mathrm{6.8)}$ for $3 \mathrm{~h}$, washed in several changes of buffer, post-fixed in $2.0^{0} 0$ osmium tetroxide for $2 \mathrm{~h}$, and dehydrated in an acetone series. Finally, they were infiltrated and embedded in a low-viscosity resin (Spurr, 1969). Silver-grey sections of selected nematodes, which were cut on a "Sorvall" model MT2 ultramicrotome using a diamond knife, were nounted on uncoated copper grids ( 75 by 100 meshi). The sections were stained for $10 \mathrm{~min}$ with 2.0 vo aqueous uranyl acetate, and then for 5 min with $3.0 \%$ lead citrate. The stained thin sections were vicwed with a "Hitachi" model H500-H iransmission electron microscope operating at $75 \mathrm{kV}$ with 30 -km apertures.

\section{Host specificity}

Host specificity to CNP was determined on the basis of attachment of bacterial endospores to the cuticles of the plant nematodes and incidence of diseased cyst on roots of host crop plants (table II). Usually, only the $\mathrm{J} 2$ (infective second stage juvenile) were available from root explant cultures. Hov sver, when other stages (i.e., eggs, third and fourth vermiform larval stages, and adult males) were availa- ble, they were also examined for possible attachment by the bacterial endospores. The $J 2$ taken from cultures were counted in a Hawksley chamber (Southey, 1986), adjusted to $300 \mathrm{~J} 2 \mathrm{per} \mathrm{ml}$, and added to the endospore suspension in a 50 -mm diameter Petri dish. To prepare suspensions of the infective endospores of CNP, a few hundred diseased cysts of $H$. glycines that were infected with CNP were handpicked from the roots of soybean. The cysts were crushed to liberate the mature sporangia. The heavy sporangial suspension that resulted was filtered through a 500-mesh wire sieve to remove the cuticular debris of the nematode. A haemocytometer was used to count the number of sporangia in the susperision, and adjust the concentration to $5 \times 10^{5} / \mathrm{ml}$. In the attachment trials, $50 \mathrm{ml}$ of the suspension was auded to equal volumes of tapwater containing 1000 $\mathrm{J} 2 / \mathrm{ml}$ of the target nematode.

Suspensions of $\mathrm{J} 2$ and endospores were poured into a shallow pan containing less than $1 \mathrm{~cm}$ of water and then placed on a rotary shaker $(50 \mathrm{rpm})$ for 24 to. $3 \mathrm{~h}$. The suspension was aerated to maintain the juveniles capati: of penetrating plani ruots. Samples of $j 2$ were taken and cxamined at $250 \times$ to determine the level of endospore attachment to the cuticular surfaces of J2. When three to ten endospores had attached to a majority of $\mathbf{J} 2$, t around the roots of host plants to allow the bacterium the epporiunity to complete its life cycle on its nematode host. After 45 days, host plants of the nematodes were harvested and their roots were exasinned for the incidence of diseased nematodes.

\section{RESULTS AND DISCUSSION}

\section{Light microscopy}

Measurements of the CNP strain from cysts that were crushed on microscope slides in tapwater were compared with the three known spe-

Figs. 1 and 2. Photomicrographs of sporangia of $p$. penetrans.

Fig. 1. Sporangia fron a crushed parasitized female RKN, $M$. intognita. Bar $=10$ um. Fig. 2. Juvenile of $M$. incognite with endospores of $P$. penetrans athided to its cuticular surface. Bar $=10 \mu \mathrm{m}$.

Fig. 3. Photomicrograph of life stages of the $F$. nishizdive sp, fov. parasite of $H$. gbjines.

Early vegetative stages, canliflover stage, quants of sporangia, single mature sporangium. $\mathrm{Bar}=10 \mathrm{gm}$. Inset illustrates numerous mature sporangia of CNP. Bar $=10 \mathrm{gm}$. 


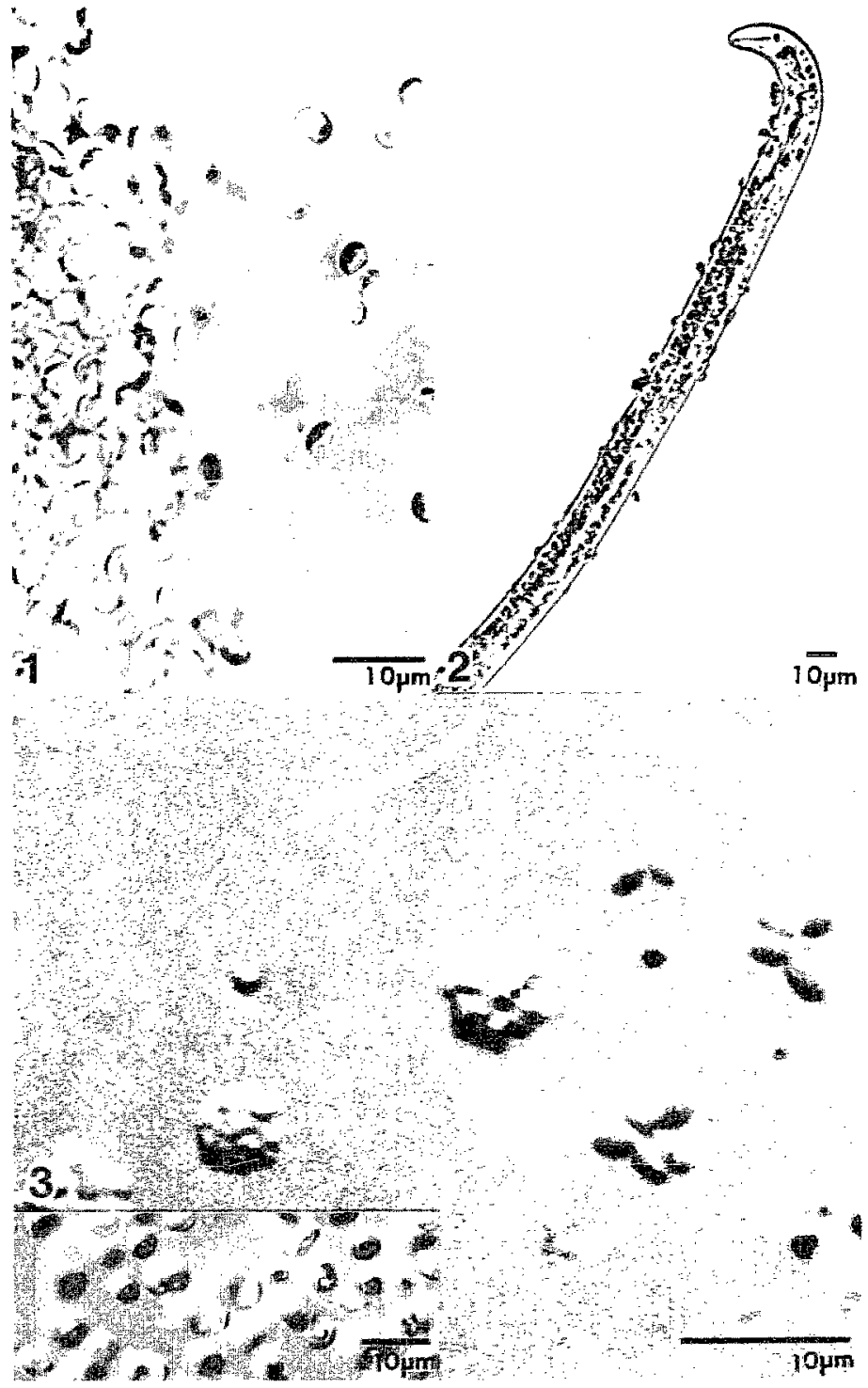


Table I. Comparison of $P$. ramosa, $P$. penetrans, $P$. thornei, and the $P$. sp. from cyst nematodes.

\begin{tabular}{|c|c|c|c|c|}
\hline Trait & P. ramosa (WFP) & P. penetrans (RKP) & P. thornei (RLP) & P. nishizawe sp. nov. (Cl \\
\hline Colony shape & Like cauliflower floret & $\begin{array}{l}\text { Spherical, to cluster } \\
\text { of elongated grapes }\end{array}$ & Small, elongate clusters & $\begin{array}{l}\text { Spherical, to cluster } \\
\text { of elongated grapes }\end{array}$ \\
\hline \multicolumn{5}{|l|}{ Sporangia: } \\
\hline $\begin{array}{l}\text { shape } \\
\text { diameter }(\mu \mathrm{m})\end{array}$ & Teardrop-shaped & Cup-shaped & Rhomboidal & Cup-shiaped \\
\hline LM & $3.3-4.1\left(^{*}\right)$ & $4.5 \pm 0.3$ & $3.5 \pm 0.2$ & $5.3 \pm 0.3$ \\
\hline $\begin{array}{c}\text { TEM } \\
\text { height }(\mu \mathrm{m})\end{array}$ & $2.12-2.77(* *)$ & $3.4 \pm 0.2$ & $2.4 \pm 0.2$ & $4.4 \pm 0.3$ \\
\hline LM & $4.8-5.7\left(^{*}\right)$ & $3.6 \pm 0.3$ & $3.1 \pm 0.2$ & $4.3 \pm 0.3$ \\
\hline TEM & $3.4-4.35\left(^{(* *}\right)$ & $2.5 \pm 0.2$ & $2.2 \div 0.2$ & $3.1 \pm 0.3$ \\
\hline $\begin{array}{l}\text { sporangial wall's } \\
\text { fate at maturity } \\
\text { of endospore }\end{array}$ & $\begin{array}{l}\text { Remains rigidly in place; } \\
\text { external markings divide } \\
\text { sporangism in thre parts }\end{array}$ & $\begin{array}{l}\text { Basal portion collapses } \\
\text { inward on the developed } \\
\text { endospore; no clear } \\
\text { external maríngs }\end{array}$ & $\begin{array}{l}\text { Remains rigid, sometimes } \\
\text { collapsing at bases; no } \\
\text { clear external markings }\end{array}$ & $\begin{array}{l}\text { Basal portion } \\
\text { collapses on the } \\
\text { developed endospore; } \\
\text { no cleas cxičninal } \\
\text { markings }\end{array}$ \\
\hline eziosporium & Not observed & $\begin{array}{l}\text { Present, relatively } \\
\text { smooth surface }\end{array}$ & Present, smooth & $\begin{array}{l}\text { Present, velutinous } \\
\text { to hairy surface }\end{array}$ \\
\hline stern cell & $\begin{array}{l}\text { Remins attached to most } \\
\text { sporangia }\end{array}$ & $\begin{array}{l}\text { Rarely seen; attachment } \\
\text { of a second sporangium } \\
\text { sometimes observed }\end{array}$ & $\begin{array}{l}\text { Neithet stem cell nor } \\
\text { second sporangium seen }\end{array}$ & Occasional seen \\
\hline
\end{tabular}

Endospore: shape

orientation of major axis to sporangium base diameter (um)

$\begin{array}{ll}\text { LM } & 2.1-2.4(* * *) \\ \text { TEM } & 1.2-1.5(* *) \\ \text { height }(\mu \mathrm{m}) & \\ \text { LM } & \\ \text { TEM } & 1.37-1.61\left({ }^{* *}\right) \\ \text { partial epicort- } & \text { Not observed }\end{array}$

Pore:

presence characteristics

diameter $(p m)$

Parasporal siructures: finters, origin and orientation
Oblate spheroid, an ellipsoid, narrowiy elliptic in section

Vertical

Not observed

\section{Oblate spheroid, an ellipsoid broadly elliptic in section}

Horizontal
Oblate spheroid, an ellipsoid sometimes almost spherical, narrowly elliptic in section Horizontal

$1.6 \pm 0.1$

$1.3 \pm 0.2$

$1.5 \pm 0.1$

$1.1 \div 0.1$

Surrounds endospore somewhat sublaterally
Oblate spheroid, an ellipsoid, nartowly elliptic in section

Horizontal

$2.1 \pm 0.2$

$1.6 \pm 0.2$

$1.7 \pm 0.1$

$1.3 \pm 0.1$

Entirely surrounds endospore
Absen?

Long primary fibers arise laterally from cortical wall, bending sharply downward to yield numerous secondary fibers arrayed internally towardthe granular matrix
Present

Basal annular opening formed from thickened outer wall

$0.3 \pm 0.1$

Fibers arise directly from cortical wall, gradualiy archïrg downward to form an antachment layer of numerous shorter fibers
Present

Basal cortical wall thins to expose inner endospore

$0.1 \pm 0.0$

Long fibers anise directly from cortical wall, bending sharply downward to form an attachment layer of numerous shorter fibers
Present

Thickness of basal wall constant and is the depth of pore $0.2 \pm 0.0$

Same as $P$. penetruns but additional layer is formed on obverse surface of endospore 
matrix, at maturity

Host

Completes life cycle in nematode juveniles

Location in host

Attachment of spores on host

Mode of penetration of host

Source of host
Cladocerans:

Daphnia; Moina

Persists as fine granular

material

Becomes coarsely

granular; lysis occurs;

sporangial wall

collapses; base is

vacuolate

RKN:

M. incognita

$\mathrm{No}$, only in aduls

Hemocoel and musculature; sometimes found attached to coelon walls

Spores not observed to attach or accumulate on surface of cladoceran

Not known; suspected to occur through gut wall
Pseudosoelom and musculature; no attachment to coelom walls seen Spores accumulate in large numbers en cuticular surface

Direct penetration of nematode cuticle by hyphal strand
Direct. penetration Soil, plants
Persists, but more granular; some strands are formed and partial collapse may occur

Root-lesion nematodes:

P. brachyurus

Yes, in all larval stages and adult

Pseudocoelom and musculatme; no attachment to coelom walls seen Spones accumulate is large numbers on cuticuatar surface suspecteả but not seen

Persist, numerous strands are formed and partial collaspe may occer

Cyst nematodes:

Heterodera spp.

No, only in adults

Pseudacoelom and musculature; no attachment to colom walls sess Spores accumulate of juventiles, rase on adult male

Direct penetration suspated but nôt serii

Sol, plants Soil, piants

(*) Sayre et al., 1983. (**) Sayre and Starr, 1989. (**) Sayre and Stars, 1985.

Table II. Host specificity of CNP (the Pasteuria species from cyst nematodes) as scored by attachinents of endospores to nematode juveniles.

\begin{tabular}{|c|c|c|}
\hline $\begin{array}{l}\text { Nematodes from which } \\
\text { endospores originated on: }\end{array}$ & $\begin{array}{l}\text { Attachment tried for } \\
\text { these nematodes }\end{array}$ & $\begin{array}{l}\text { Attached }(+) \text { or } \\
\text { non-attached }(-)\end{array}$ \\
\hline \multirow[t]{8}{*}{ Heterodera glycines } & Race $1 H$. glycines & 4 \\
\hline & Race $3 " \#$ & + \\
\hline & Race $4 " *$ & + \\
\hline & Race $5 " *$ & + \\
\hline & Heterodera trifolii & + \\
\hline & Heterodera sp. & + \\
\hline & Heterodera sp. & - \\
\hline & Meloidogyne & - \\
\hline \multirow[t]{11}{*}{ Heterodera elachista $\left(^{*}\right)$} & Globodera rastochtenis & + \\
\hline & Helicotylenchus sp. & - \\
\hline & Heterodera sp. & + \\
\hline & Heteroutera sp. & + \\
\hline & Meloidogyne hopla & - \\
\hline & Meloidogyne incognita & - \\
\hline & Meloidodyne jovanicu & - \\
\hline & Protylenchus coffeae & - \\
\hline & Pratylenchus penetrans & - \\
\hline & Pratylenchus vulntes & - \\
\hline & Vartous saprophagous & - \\
\hline
\end{tabular}

(*) Data preptred by Di. T. Nishizawa. 


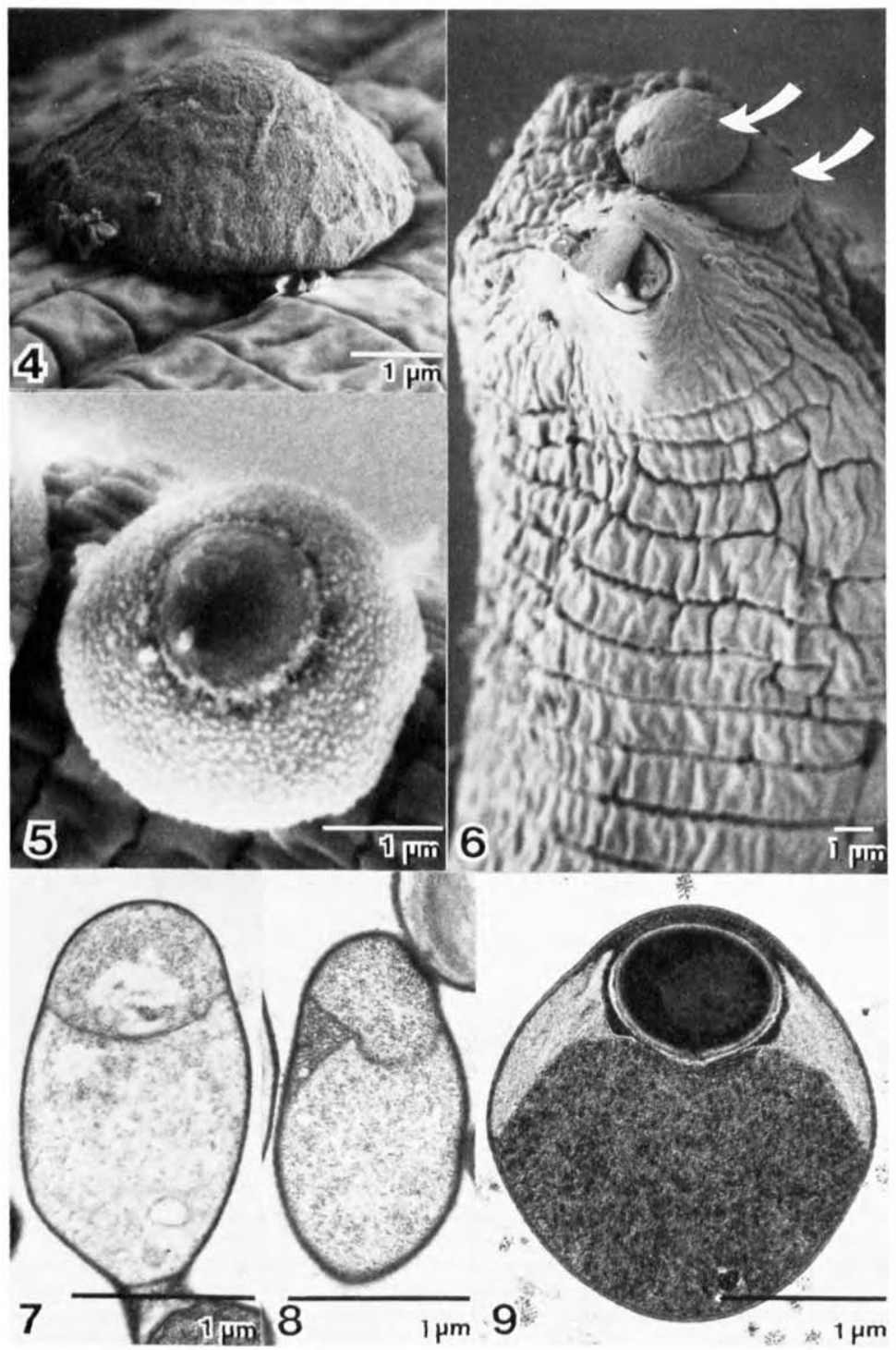


cies of Pasteuria (table 1). The mature sporangia of CNP averaged $5.3 \mu \mathrm{m}$ in diameter (fig. 3 ). The average height, from the margin of the dome of the central body to the base of the sporangium, was $4.3 \mu \mathrm{m}$. The central body had the shape of an oblate spheroid, with axes of $1.7 \pm 0.1$ by $2.1 \pm 0.2 \mu \mathrm{m}$ and was enveloped laterally by episporic fibers.

An individual sporangium in the immature quartet stage had a diameter of $1.8 \mu \mathrm{m}$ and measured $3.2 \mu \mathrm{m}$ in height from its point of attachment to the distal end (fig. 3 ). In the doublet configuration, the sporangium had a diameter of $4.1 \mu \mathrm{m}$ and a height of $3.9 \mu \mathrm{m}$.

Light microscopy revealed significant size differences among the described species of Pasteuria (table I). These differences, in conjunction with the specificity of bacterial spore attachment to nematode species, served as a reliable indicator of strain differences and aided in the taxonomic characterization. Sporangia of CNP were larger than the other two bacterial isolates from nematodes; however, they were not the largest found in the genus. Another isolate of Fusteuria, which parasitizes Hoplolaimus spp., is much Iarger (i.e. $7 \mu \mathrm{m}$ in diameter) and may be a different Pasteuria spp. (Sayre et al., 1988). The numbers of sporangia in females of the root-knot nematodes (RKN) were nearly four-fold greater than those found for CNP in cyst nematodes. This difference was partly due to the larger volume of the RKN females as compared to smaller cysts of SCN and to the larger size of the CNP sporangia. In the veriform Pratylenchus spp., each stage of the nematode contained only a few hundred sporangia.

\section{Scanning electron microseopy}

Mature endospores of CNP with their episporal structures and associated perisporic remnants were found adhering to the surfaces of $\mathrm{J} 2$ and adult males of $H$. glycines (figs. 4 to 6). Two distinct forms of endospores occurred, which is similar to the situation for $P$. penetrans. In one form, the surface of the endospore was covered by the exosporium; in the other, the episporic wall structures were exposed. The surface of the first form appeared to be covered by a velutinous membrane, the exosporium, that encompassed the entire endospore (figure 4). In the other form, the exosporium had shed to expose an underlying central body, averaging $1.5 \mu \mathrm{m}$ in diameter and $1.2 \mu \mathrm{m}$ in tseight, that was surrounded by episporic fibers (figure 6).

The resolution and definition of the $L V F E$ SEM for viewing sporangia was far superior to that of LM. In particular, LVFE-SEM revealed remarkable details of the external morphology of sporangia and endospores of CNP that were

Figs. 4, 5 and 6. Scanring electron micrograptes oí CNP.

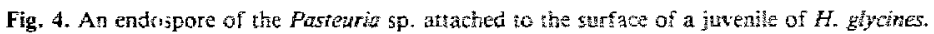

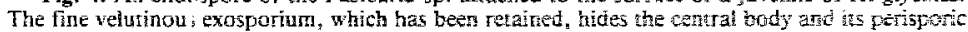
Thres. Bar $=1$ um.

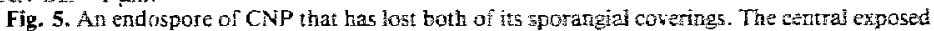

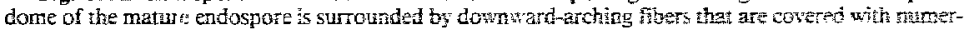
ous hairlike projugtions.

Fig. 6. The posterior of the male $H$. gitcines. Two endospores (arrons) are artached fear the slightiy extendec spickle. Bar = 1 part.

Figs. 7, and 9. Transmission electron mierograph of immature sporandic of CNP.

Fig. 7. Ov" te terminal cell of a microcolony with a septum that separates the forepore.

Fig. 8. A resosome associated with the developing sporangizm. Bar $=1$ timl.

Fig. 9. A the developmental stage in a sporangium of CNP. Seweral this spore cotis have differed liated, but the peripheral fibers remain as ill defined white areas. Bar $=1$ ism. 

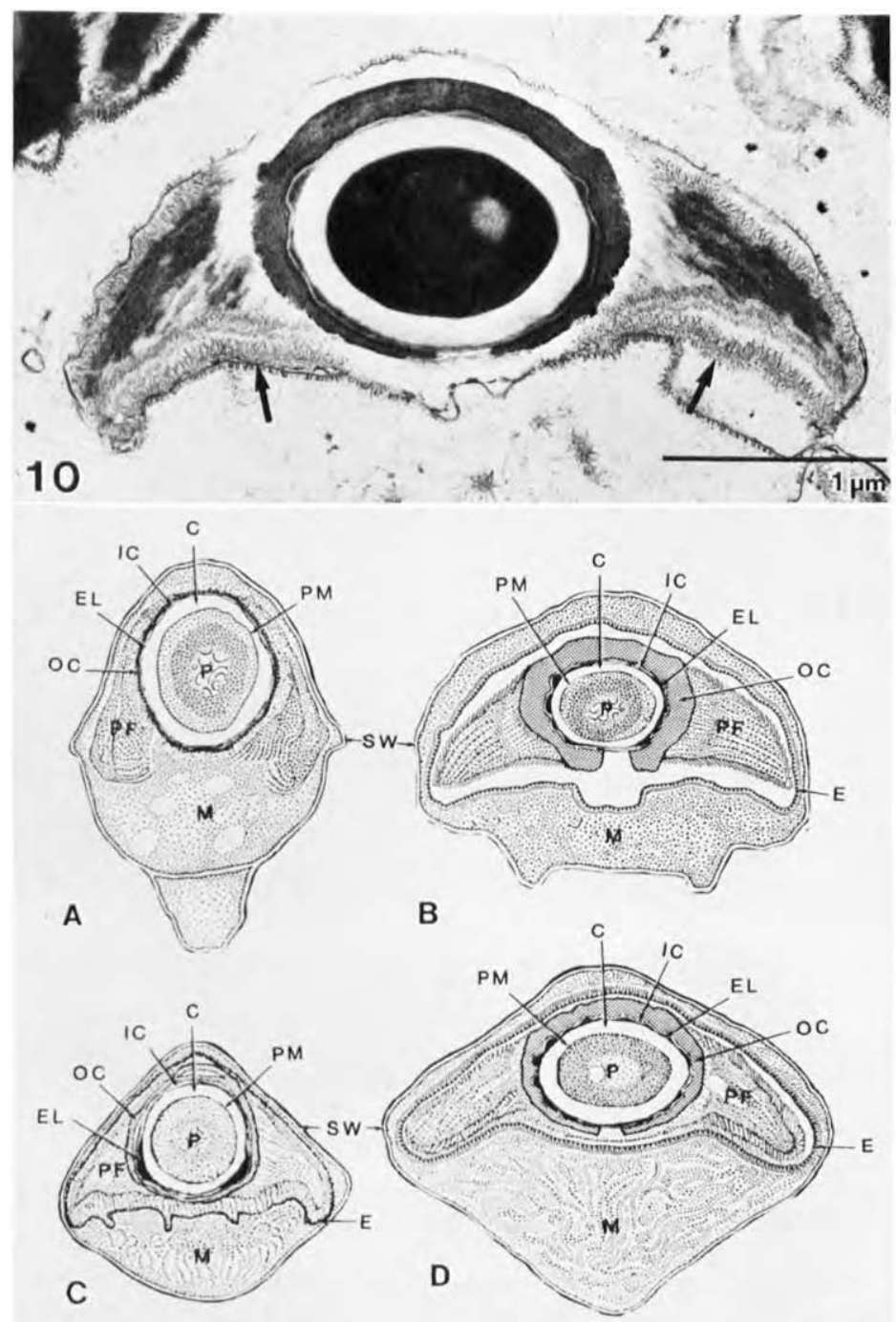

11 
not visible by $\mathrm{LM}$. The textural appearance of the episporic wall coverings will be useful in delineating new taxons.

\section{Transmission electron microscopy of CNP}

\section{Vegetative growth and sporogenesis}

The developmental stages (i.e. growth, vegetative, mycelium and endosporogenesis) of CNP occurred in the distal or terminal cells of the dichotomously branching hyphal colonies. These cells were bounded by a compound wall, about $0.04 \mu \mathrm{m}$ thick, composed of outer and inner membranes. The inner membrane constricts during the formation of septa that delineated successive cells, which enlarge and become ovate (fig. 7). The protoplasts of the ovate cells change from that having a granular matrix with numerous ribosomes to one with well-defined organelles. Mesosomes were often found associated with septa in thin sections of CNP (fig. 8). During the early development of the sporangia, transverse membranes formed within the cell and separated one-third of tine distal end of the sporangium, the forespore, from the lower/basal parasporal portion. The proioplast in the upper portion of the cell condensed into an electron-dense central core that become encircled by a multilayered wall (fig. 9). After these changes occurred, the electron-translucent parasporal region developed laterally with respect to the endospore. Development of the parasporal region began with the appearance of lateral fibers, thickening of the multilayered en- dospore walls and the formation of the ellipsoidal endospure (fig. 9). Stages of endogenous spore formation of all Pasteuria sp. were typical of Gram-positive bacteria; but the formation of a fibrillar episporic wall distingutshes the genus Pasteuria from the genus Bacillus.

\section{Mature sporangia}

In a lateral view, sporangia of CNP retained a lenticular shape, which persisted until the outer sporangial wall degraded and exposed the veluininous exosporium. As a rasult, the endospore and its accompanying peripheral fibres become cup-shaped (figs. 10 and 11). The mature CNP endospore had a broadky elliptical central body whose axes measured $1.6 \pm 0.2$ by $1.3 \pm 0.1 \mu \mathrm{m}$. The outer cortical wall was $0.2 \mu \mathrm{m}$ thick at the mid-point of the endospore, but progressively tapered to $0.1 \mathrm{um}$ at the periphery of the pore. The partial hirsute layer, originating from the basal adhesion layer of the endospore, is a unique morphological feature of CNP (fig. 10), which was not fourd in other members of the $P$. penetrans group that we examined. Mature sporangia of water flea Pasteuria (WFP), root-knot Pasteuria (RKP) and root-lesion Pasteuria (RLP) appeared distinctly different from each other (fig. 11): sporangia of WFP were teardrop-shaped; those of RLP appeared rhomboidal; and RXP and CNP had a cup-shaped configuration. Additional differences that separated the latter two species included the physical arrangement (i.e. numbers and angle of fibre attachment) of the

Fig. 10. Transmission electron micrograph of a cross section of an thacspore of the Pasteria sp. found in cyst nematodes (C)

The additional partial layer (anows), which is urique to this species of Pasterta, can be observed on the obverse surface of the endospore. Bar $=1 \mathrm{~km}$.

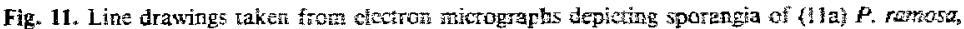
(11b) $P$. penetrans, (11c) $P$. thornel and (11 d) $P$. nishizawae sp. nov.

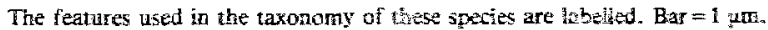

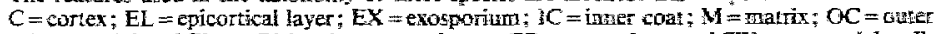

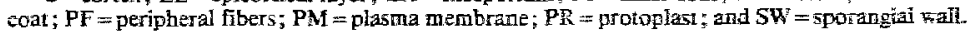


peripheral fibres that occurred on the cuter coats of their endospores. Qualitative differences that distinguished CNP from $P$, penetrans and $P$. thornel were associated with the spore coats. The epicortical layer of CNP completely surrounded the cortex, but was incomplete in the other two species. In addition, the depth of the basal pore of CNP reflected the thickness of the endospore wall. In the case of $P$. penetrans, the wall thickened and became doughnut-shaped around the pore. Alternatively, in $P$. thornei the wall thinned and resulted in an opening at the base of the endospore (fig. 11c).

The additional pertial wall found in CPN was unique for a Pasteuria spp. It occurred on the observe face of the endospore and appeared to be formed from the attachment layer (fig. 10). Its function was not determined. The attachment of CNP endospores to males of $H$. glycines also helped distinguish it fron the other two Pasteuria spp. that attach only to $\mathbf{J} 2$.

\section{Life cycle of $\mathrm{CNP}$}

Similarities between the life cycles of CNP and $P$. penetrans are summarized in table 1 . All life stages, except the inature sporangium of CNP, presented the same morphological appearance as those of $P$. penetrans. The developmental stages of CNP were in synchrony with those of its cyst nematode host; this was also the case for the Pasteuria found in RKN. This synchronous, development was absent in $P$. thornei where the bacterial species apparently can completes its life cycle in any developmental stage of the nematode host.

A significant difference between CNP and $P$, penetrans was the ability of the endospores to attachment to the adult males of $H$. glycines (fig. 6). However, completion of the bacterium's life cycle within males has not been observed.

\section{Hast range studies of C $\mathrm{NP}$}

To establish the host ranges of CNP, RKP and RLP, we examined the ability of the endospores to attach to the respective $\mathbf{J} 2$ of the host ; attachment was used as the criterion of susceptibility to the bacterial disease (fig. 2 and table 11). The nematode hosts that we examined were restricted largely to the RKN and cyst nematodes. Endospores of CNP attacheci to the cyst nematodes but not to the RKN or the other plant-parasitic and free-living species that were tested. Conversely, endospores from RKN did not attach to J2 of cyst nematodes. The host range of CNP was unique; this was the first documented case of a Pasteuria species on cyst nematodes (Nishizawa, 1984), which included four species of Heterodera and the single species $G$. rostochensis (table 1 I). However, over 60 other species of cyst nematodes exist which have not been screened for their susceptibility to CNP; therefore, additional hosts are likely and undescribeo species of Pasteuria may be capable of parasitizing other cyst nematodes. In fact, another distinct isolate of CNP may have already been found by Bhattacharya et al. (1988) who recentiy reported that several Heterodera spp." were parasitized by a $P$. penetrans sp.; however, their bacterium parasitized $H$. zeae and $M$. incognita while ours does not.

The nematode hosts of Pasteuria spp. include about 175 species in nearly 70 genera from 10 orders (Starr and Sayre, 1988; Sturhan, 1985). Nematodes from each taxon have different feeding habits and life cycles that vary in duration. Therefore, each nematede species has a slightly different physiology. In order to survive, selection pressure favoured the bacterium whose physiology paralleled that of a particular nematode host. The one-to-one relationship that exists between these bacterial parasites and their nematode hosts suggests that the genus Pasteuria contains numerous unique bacterial species.

Morphological differences among the four bacteria investigated in this study lead us to conclude that the CPN isolate should be assigned a new epithet.

\section{TAXGNOMIC FORMALITIES}

Description of Pasteuria nishizawae sp. nov. Pasteuria nishizawae sp. nov. (ni.shi.za'wae M. L.

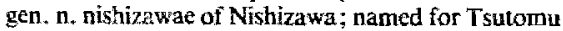


Nishizawa, Japanese nematologist, who discovered and first investigated bacterial parasites of cystforming nematodes).

Gram-positive vegetative cell. Mycelium is septate, hyphal strands, $0.2-10.5 \mu \mathrm{m}$ in diameter, branch dichotomously. The sporangia, which form by expansion of hyphal tips, are cup-shaped and measure about $4.3 \mathrm{fm}$ in height and $5.3 \mathrm{sm}$ in dianeter. Each sporangium is divided into unequal parts. The smaller proximal body is not as refraetile as the larger, rounded cup-shaped portion, which encloses an ellipsordal central body. The central body, which is broadly et liptic in cross-section, having an axis of $1.7 \times 2.1 \mathrm{\mu m}$, is surrounded laterally by perisporic fibers originating in the outer coat wall. The endospore, which is typical of the genus Bacillus, is resistant to heat and desiccation. Sporangia and vegetaive cells are found in the pseudocoelom of the infected cyst-forming plant-parasitic nematodes. The epithet is now restricted to members of the genus Pasteuria with cupshaped sporangia having central bodies that are broadly elliptic in cross section. They occur primarily as parasites of the adult female nematodes beloriging to the genus Heterodera and Globodera; they may parasitize other plant-parasitic nematodes. Has not been cultivated axenically; the iype descriptive material consists of the text and photographs herein. $P$. nishizanae difters from $P$. penetrans, $P$. thornet and other members of Pasteuria in host specificity, i: size and shape of sporangia and endospores and in other morphological and developmental characteristics.

\section{Acknowledgements}

We are gratetul to Dr. D. Sturian for the shazed discussion on this research dutring the recent AID bitateral German/American exchange in agricuinural researct.

Also, we thank Drs. L. Franct and R. Ginerna Ion theis critical reading and suggestions relating to the mazuscript; to Phoebe isetty Starr for skined bibliographic and redactitonal assistance; 10 Robert Ewing who drafted f fogtre 11 ; to C. Pooley, G.H. Kaminsti, R.W. Raxice, N. Lathe and S.V. Blohm for their proficient achnical assistance.

\section{Pasteuria nishizawae sp. nov., bacté-ie à nycelium et formant une endospore parasite des nématodes à kystes du genze Heterodera el Globodera}

Dans catle étude est técrite une esiecer rowvelte, Pasreuria nishizawe, la se espece du genta Pastewria. Cette backérie à mycelinm ei formant une endospore, parasite les femelles adultes des nématodes dis genre Heterodera a Glabodera. Des caranteres uthastrueturaux distincs et une uniqus ganthe do dhotes trours pour cette bactétit, la sçparent de deux tespónces étroitement apparentces, â savoir $P$. penerrans qui parasite plusiears espoces de nematodes des nouds raciniaires des plantes, du genre Meloidogwe, et de $P$. thomei qui semble parasifer seulemeat une seule espece de nématode des lésions racianaires. Protylenchus brachyurus, Etant donae que ces parasites bacteriens obligés des nématodes n ont pas pu être cultivés de façon axénique, la description des liens de parenté caxonomique pour chague espece. est basée principalement sur la morphologie du dêté loppement, sur to stucture fine des sporanges et endospores respectifs, et sur le pour oit pathogene sut les diserses espèces de nématodes.

Mots-ciés: Pastentia Partearia nishizowe, Sol, Nëmarode, Lume biologigut: Nouvelle etsoce, Taxonomie.

\section{References}

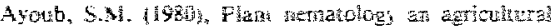

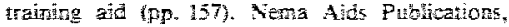
Sacrativento, CA 95014.

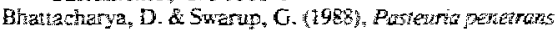
a pathogen of the genas Heteraderk, it5 efect on

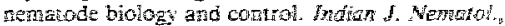
15, 5 蒠 70 .

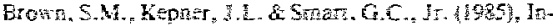

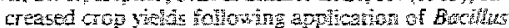

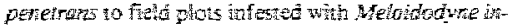

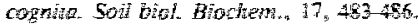

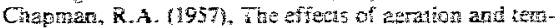

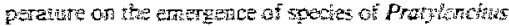

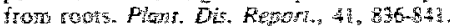

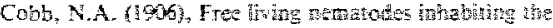

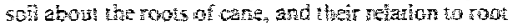

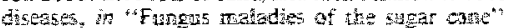

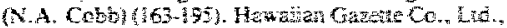
Hornonity?

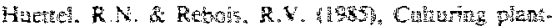

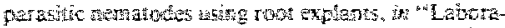

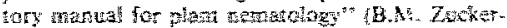

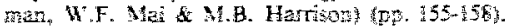

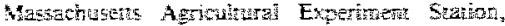
A wherst.

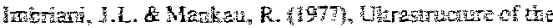

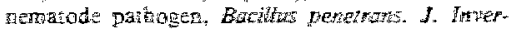

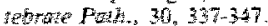

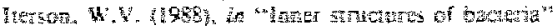

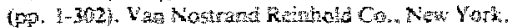

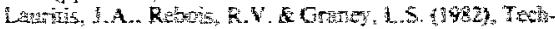

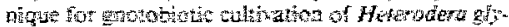

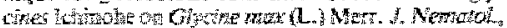
$14,422+24$

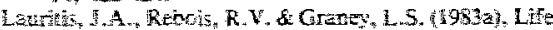

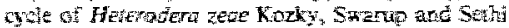


on Zea mays $\mathrm{L}$. axenic root explants. J. Nemasol., $15,115+119$.

Lauritus, J.A., Rebooss, R.V. . Grancy, L.S. (1983b), Development of Heterodera glacines lichinche on soybean, Glycine max (L.) Merr., under grnotobiotic conditions. J, Nemasol., 15, 272,281.

Mankau, R. (1973), Utilization of parasites and predalors in nematode pes! management ecology, in "Tals Timbers Conference on Ecological Animal Control by Habilat Management". Proceedings, 4, 129-143.

Mankau, R. (1975a), Bacillas penetrans n. comb. causing a virulent disease of plant-parasitic nematodes. I. Invertebr. Path., 26, 333-339.

Mankau, R. (1975b), Prokaryote affinities of Duboscqia penetrans, Thorne. J. Protozool., 21, 31-34.

Mankau, R. (1980), Biological control of nematode pests by natural enemies. Anst. Rev, Phytopath., 18, $415-440$.

Mankau, R. Prasad, N. (1972), Possibilities and problems in the use of a sporozoan endoparasite for biological control of plant parasitic nematodes. Nematropica, 2,7-8.

Mankau, R. \& Prasad, N. (1977), Infectivity of Bacillus penetrans in plant-parasitic nematodes. J. Nematol, $9,40-45$.

Niblack, T.R \& Huang, R.S. (1985), Extracting nematodes from soil and plant tissue, in "Laboratory manual for plant nematology, Exercise 34" (B.M. Zuckerman, W.F. Mai, \& M.B. Harrison) (pp. 201-206). Massachusetts Agricultural Experiment Station, Amherst.

Nishizawa, T. (1984), Efferts of two isolates of Eacthus penetrans for control of root-knot nematodes and cyst nematodes, in "Proceedings of the First international Congress of Nematology" (pp. 60-61).

Nishizawa, T. (1986), On a strain of Pasteuria penetrans parasitic lo cyst nematodes. Rev. Nénatol., 9, $303-304$.

Nishizawia, T. (1987), A declire phenomenon in a population of upland cyst nematode, Heterodera elochista, caised by bacterial parasite, Pasteuria penetrans. J. Nematol., 19, 546 .

Sayre, R.M., Gherna, R.L.\&Wergin, W.P. (1983), Morphological and taxonomic reevaluation of Pastewria rcmosa Mefchnikoff 1888 and "Bacilles penetrans" Mankau 1975. Int, J. sys:. Bcet, 33, 636-649.

Sayre, R.M. \& Starr, M.P. (1985), Pastetria penerrans (ex Thorne 19-40, nom, sev., comb. n., sp. n., a mycelial and endospore-forning bacterium parasitic in piantparasitic nematodes. Proc. helnzinth. Soc. Wash., 52, 149-165.

Sayre, R.M. \& Start, M.P. (1989) Genus Pasteuria Metchnikoff 1888 , $166^{\text {Al }}$ emend. Sayte and Stars 1985. 149, Starr and Sayte 1988a, 27 (Nom. Cons. Opin. 61 Jud. Comm. 1986, 119. Not Pastermo in the sense of Henrici and Johnson (1935), Hirsch (1972) or Sualey (1973) ; se Starr el al (1983) ant Judicial Commission (1986), in "Bergey"s manual of systematic bacteriology, wolume 4 " (S.T. Whans at at.) (pp. 2601-2614). Williams \& Wikins, Baltinore, ND. Sayre, R.M., Star, M.P., Golden, A.M. Wergin, W.P.
\& Endo, B.Y. (1988), Comparison of Pcsteuria peneIrans from Meloidogyne incognita with a related snycelial and endospore-forming bacterial parasite from Praylenchus brachyurtas. Proc. helminth. Soc. Wosh., 55, 28-49.

Sayre, R.M. \& Wergin, W.P. (1977), Bacterial parasite of a plant nematode: morphology and ultrastructure. J. Bact., 129, 1091-1101.

Sayre, R.M., Wergin, W.P., Nishizawa, T. \& Star, M.P. (1991), Light and electron microscopy studies of a bacterial parasite from cyst nematodes of the genera Heterodera and Globodera. Proc. helinimih. Soc. Wosh., 58, 69.81.

Soutkey, J.T. (1986), Laboratory methods for work with flant and soil nematodes, sixth edition (pp. 1-202). Her Majesty's Stationery Office, London.

Spurr, A.R. (1969), A low viscosity epony resin embedding medium for electron microscopy. J. Ultrastr. Res., 26, 31-34.

Star, M.P. \& Sayte, R.M. (1988), Pasteuria thornei sp. nov. and Pasteuria penetrans sensu stricto emend., mycelial and endospore-forming bacteria parasitic, respectively, on plant-parasitic rmatodes of the genera Pratylenchus and Melotdogyne. Ann. Inst. Pasteur/Microbiol., 139. 11 3!.

Stirling, G.R. (1984), Biological control of Meloidogyne javatica with Bacillus penetrans. Phytopothology, 74 , $55-60$.

Stirling, G.R. (1989), Biological control of plant-parasitic Fematodes, in "Diceases of nemarodes", Volume 2

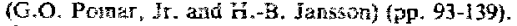
CRC Press, Boca Raton.

Stirling, G.R. \& Wachtel, M.F. (1980), Mass production of Bacilus penetrans for the biological control of roat-knot nematodes. Nemarologica, 26. 2ise-312.

Sturhan, D. (1985), Untersuchungen uber Vex $\therefore$ in isig und Wirte des Nematodesnparasiten Bacillus pehetrans. Miti. Boil. Btindesanstalt Land-und Forstwirtschaft, $226,75.93$.

Sussman, A.S. \& Halvorson, H.O. (1966), in "spores their dormancy and gemination" (pp. 1-354). Harper and Row, New York.

Thome, G. (1940), Duboscqia penetrans n. sp. (Sporczca: Microsporidia, Nosematicae), a parasite of the nematode Pratylenchus pratensis (de Man) Filipjev. Proc. helminth, Soc. Wash., 7, 51-53.

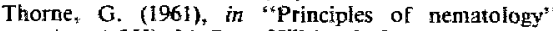
(pp. 1-553). McGraw-Hill Book Co., New York.

Wergin, W.P. \& Sayre, R.M. (1988), Applications of low voltage fiald emission SEM to nematology. J. Nomoto $t, 20,821$.

Wergin, W.P., Sayre, R.M. \& Reilly, T.W. (1988), Lowvolnage field-emission scanning electron microscopy applications in nematurogy, in "Proceedings of the electron microscopy society of America" (G.W. Bailey) (Pp. 420-421). San Francisco Press. Lac., CA.

Williams, J.R. (1960). St udfes on the nematode soil fauna ố sugarcane fields in Mauritus. -5 . Notes upon a parasite of root-knot nematodes. Nemanolagica, 5 , $37-42$. 